\title{
Reperfusion Therapy of Myocardial Infarction: From Classic to Modern Fibrinolysis
}

\author{
Marcelo Trivi* \\ Chief of Clinical Cardiology ICBA, Buenos Aires, Argentina
}

Submission: May 02, 2017; Published: May 31, 2017

*Corresponding author: Marcelo Trivi, Chief of Clinical Cardiology ICBA, Buenos Aires, Argentina, Email: mstrivi@icba.com.ar

\section{Opinion}

One of the main changes occurred in medicine in the last 25 years has been reperfusion treatment in acute myocardial infarction. From management of complications to immediate intervention in STEMI has come a long way.

Four decades ago, STEMI treatment pointed to complications management, mainly arrhythmic (Ventricular fibrillation or AV block) or mechanics (cardiogenic shock, VSD, cardiac rupture or expansion). Intervention era started with intracoronary fibrinolysis, which quickly evolved to endovenous approach.

Fibrinolytic treatment was a landmark as the beginning of the "reperfusion era" in STEMI. But it also was the beginning of bleeding complications in acute coronary syndromes, and its most dreaded form, intracranial hemorrhage.

Streptokinase, the historically (and currently) most used fibrinolytic drug is far from ideal: in addition to a low reperfusion rate (TIMI 3 flow around 60\%), it must be used by intravenous infusion and it has other problems as immunogenicity (which conditions allergies and antibodies) or hypotension, a big issue in patients with severe heart failure or cardiogenic shock. Besides, the success of fibrinolysis (as occurs in stroke) is very time-dependent, being clearly more effective within 1st hour of myocardial infarction. Culprit artery re-occlusion is an additional problem. New (and more expensive) fibrin specific drugs, such as tpA (alteplase), rpA (reteplase) and TNK-tpA (tenecteplase), tried to overcome these problems. In fact TNK, the most modern of them, has several advantages: is fibrin-specific, used by intravenous bolus and it does not induce hypotension or immunogenicity.

At the same time, percutaneous coronary intervention (PCI) was started on its way in STEMI. It was first used after failed fibrinolysis, and then it evolved quickly to primary intervention. Today direct PCI with stent is the 1st line treatment for STEMI and is recommended by all guidelines [1,2]. Even if the patient should be transferred (within 2 hours), PCI is recommended over fibrinolytic therapy.

However, not all medical centers count on equipment and qualified/experienced staff (as also recommended by guidelines) "on call" with fast response. So as fibrinolytics continue to be used, then the idea of combining fibrinolytics with PCI appeared as alternative approach. There are several options of PCI plus fibrinolytics as shown in Table 1.

Table 1: Types of PCl plus fibrinolytics in STEMI.

\begin{tabular}{|c|c|c|}
\hline Type & Scenario & Effect \\
\hline Rescue & Post failed reperfusion & + \\
\hline Facilitated & Immediately Pre PCI & - \\
\hline Pharmacoinvasive & PCI 3-24 hours post & ++ \\
\hline Deferred & More than 24 hours & \pm \\
\hline
\end{tabular}

Facilitated PCI uses fibrinolytics as "pre-treatment" to improve the results of immediate angioplasty. These results were disappointing because this approach not only did not improve but it also worsened the results of PCI.

Table 2: In addition to classic fibrinolysis there is a modern fibrinolysis, with some differences but the most important: fibrinolysis is not more a definitive treatment; it is the first step to $\mathrm{PCl}$.

\begin{tabular}{|c|c|c|}
\hline Fibrinolysis & Classic & Modern \\
\hline Prescription & $\begin{array}{c}\text { Streptokinase } \\
\text { infusion }\end{array}$ & TNK bolus \\
\hline Site & Hospital & Ambulance/hospital \\
\hline $\begin{array}{c}\text { Coronary } \\
\text { angiography }\end{array}$ & Selective & Routine \\
\hline Objective & Curative & Palliative \\
\hline
\end{tabular}

Pharmacoinvasive approach instead, attempts to improve the results of fibrinolysis. The ideal protocol should be prehospital fibrinolysis with TNK, loading doses of clopidogrel and enoxaparin followed by immediate transfer for coronary angiography between 3 and 24 hours, for matching the results of 
STREAM trial [3]. This may be an effective alternative treatment when PCI is not available in the recommended time, for rural and faraway locations [4]. The time window extends from 2 to 24 hours and allows a less urgent transfer. But it seems important to stress, that this "modern approach" contrast with the "old fashioned" fibrinolysis, and this is the aim of my comment. As shown in Table 2, in addition to classic fibrinolysis there is a modern fibrinolysis, with some differences but the most important: fibrinolysis is not more a definitive treatment; it is the first step to PCI.

Finally, as well as angioplasty, fibrinolysis has evolved too, from a competitive to a complementary treatment in the reperfusion therapy of acute myocardial infarction.

This work is licensed under Creative Commons Attribution 4.0 License DOI: $10.19080 /$ JOCCT.2017.05.555667

\section{References}

1. O'Gara PT, Kushner FG, Ascheim DD, Casey DE, Chung MK, et al (2013) 2013 ACCF/AHA guideline for the management of ST-elevation myocardial infarction: a report of the American College of Cardiology Foundation/American Heart Association Task Force on Practice Guidelines. J Am Coll Cardiol 61(4): e78-e140.

2. Steg PG, James SK, Atar D, BadanoLP, Blömstrom-Lundqvist C, et al. (2012) ESC Guidelines for the management of acute myocardial infarction in patientspresenting with ST-segment elevation. Eur Heart J 33(20): 2569-2619.

3. Armstrong PW, Gershlick AH, Goldstein P, Wilcox R, Danays T, et al. (2013) Fibrinolysis or primary PCI in ST-segment elevation myocardial infarction. N Engl J Med 368(15): 1379-1387.

4. Martínez-Sánchez C, Arias-Mendoza A, González-Pacheco H, AraizaGaraygordobil D, Marroquín-Donday LA, et al. (2017) Reperfusion therapy of myocardial infarction in Mexico: A challenge for modern cardiology. Arch Cardiol Mex 87(2): 144-150.

\section{Your next submission with Juniper Publishers will reach you the below assets}

- Quality Editorial service

- Swift Peer Review

- Reprints availability

- E-prints Service

- Manuscript Podcast for convenient understanding

- Global attainment for your research

- Manuscript accessibility in different formats

( Pdf, E-pub, Full Text, Audio)

- Unceasing customer service

Track the below URL for one-step submission https://juniperpublishers.com/online-submission.php 